Gu, C and W.J.Riley (2010). "Combined Effects Of Short Term Rainfall Patterns And Soil Texture On Nitrogen Cycling In Bare Soil -- A Modeling Analysis," Journal of Contaminant Hydrology, VOL. 112, ISS.1-4. doi:10.1016/j.jconhyd.2009.12.003. Version of record available from: [ISSN: 0169-7722].

\title{
Combined Effects Of Short Term Rainfall Patterns And Soil Texture On Soil Nitrogen Cycling -- A Modeling Analysis
}

\author{
Chuanhui $\mathbf{G u}^{1}$ and William J.Riley ${ }^{2}$ \\ ${ }^{1}$ Berkeley Water Center, University of California, Berkeley, CA \\ ${ }^{2}$ Earth Sciences Division, Lawrence Berkeley National Laboratory, \\ Berkeley, CA
}




\section{Introduction}

Anthropogenic inputs of reactive nitrogen $(\mathrm{N})$ to ecosystems have led to significant environmental consequences (Aber et al., 2003; Galloway et al., 2008). Alteration of the natural $\mathrm{N}$ cycle has a direct impact on water $\left(\mathrm{NO}_{3}{ }^{-}\right)$and atmospheric pollution $\left(\mathrm{N}_{2} \mathrm{O}, \mathrm{NO}, \mathrm{NH}_{3}\right)$ (Galloway et al., 2003). Groundwater $\mathrm{NO}_{3}{ }^{-}$concentrations exceed drinking-water standards in many areas as a result of inputs from fertilized agriculture, resulting in potential human health effects (Power and Schepers, 1989; Spalding and Exner, 1993; Squillace et al., 2002). Elevated $\mathrm{NO}_{3}{ }^{-}$concentrations in leachate and surface water can also lead to eutrophication of lakes and estuaries (Lowrance et al., 1997). Nitrous oxide $\left(\mathrm{N}_{2} \mathrm{O}\right)$ is an important greenhouse gas and is involved in the destruction of stratospheric ozone (IPCC, 2001). Nitric oxide (NO) emissions contribute to tropospheric ozone formation and acid deposition (McTaggart et al., 2002). $\mathrm{NH}_{3}$ emissions affect the environment in the form of wet and dry deposition of $\mathrm{NH}_{4} \mathrm{NO}_{3}$ and $\left(\mathrm{NH}_{4}^{+}\right)_{2} \mathrm{SO}_{4}$ salts, causing acidification of poorly buffered soils and eutrophication (vanderWeerden and Jarvis, 1997). These concerns have stimulated studies to identify potential future climate change effects on $\mathrm{N}$ leaching and emissions from ecosystems (Skiba et al., 1997).

Precipitation and the resulting soil water dynamics strongly regulate $\mathrm{N}$ cycling in terrestrial ecosystems (Aranibar et al., 2004) via effects on physical transport (Brooks et al., 1999) and soil microbial $\mathrm{N}$ transformations (Corre et al., 2002). Nitrification and denitrification are thermodynamically favorable redox reactions mediated by soil microbe communities (Hedin et al., 1998). Redox status is, therefore, a primary controlling factor of these processes in soils (Bollmann and Conrad, 1998). Further, $\mathrm{N}$ losses in soils are episodic in nature. Pulses of $\mathrm{N}$ gas production associated with transient changes in soil microsite environments have been shown to account for significant surges of $\mathrm{N}$ emissions to the atmosphere in relatively short time spans (Gu et al., 2009; Li et al., 1992; Maggi et al., 2008; Riley \& Matson, 2000). Consequently, the magnitude and extent of $\mathrm{N}$ 
biogeochemical processes vary widely with changes in soil water dynamics, which are largely determined by soil (e.g., clay and soil organic matter content) and rainfall characteristics.

Many general circulation models forecast a higher frequency of extreme rainfall events, a lower frequency of rainfall days, and longer intervals of dry periods (Easterling et al, 2000; IPCC, 2007). It is well known that changes in precipitation directly alter soil water content and element cycles. An experimental study has demonstrated that increased temporal variability in precipitation and soil moisture increased plant water stress and reduced plant productivity (Knapp et al., 2002). Several modeling studies have also been conducted to address the ecosystem response to precipitation patterns (Gerten et al., 2008; Weng and Luo, 2008). However, the effect of altered precipitation variability on the soil $\mathrm{N}$ cycle, to the best of our knowledge, has not been examined in detail.

The goals of this study were to evaluate the independent and interactive effects of rainfall amount and variability on soil $\mathrm{N}$ losses via leaching and gas effluxes by using a mechanistic, process-based model (TOUGHREACT-N). TOUGHREACT-N simulates the biogeochemical cycling of nitrogen coupled with $\mathrm{N}$ aqueous and gaseous transport and losses (Maggi et al., 2008). The model has been tested against several experimental and observational datasets, and several sensitivity analyses have been performed ( $\mathrm{Gu}$ et al., 2009; Maggi et al., 2008). For this study, we modified TOUGHREACT-N by implementing soil carbon cycle. After calibrating and testing the model further using data from a field experiment in the Costa Rican Cordillera Central region (Nobre et al., 2001) that focused on the effects of short term precipitation variability on $\mathrm{N}$ gas and aqueous losses, we apply the model to explore soil water and nitrogen dynamics in response to projected changes in rainfall variability.

\section{Methods}

\subsection{TOUGHREACT-N model}

TOUGHREACT-N evolved from its precursor model TOUGHREACT (Xu et al, 2006), and is a process-based subsurface hydrology and biogeochemistry model designed to simulated soil water, heat, and chemical dynamics. We briefly describe the model here; more details are given in the appendix, Gu et al. (2009), and Maggi, et al. (2008). 
TOUGHREACT-N predicts three-dimensional multi-phase and multi-component reactive flow and transport in soils, biogeochemical processes, multiple microbial biomass dynamics, heat and water flows, and an arbitrary number of chemical reactions subject to local equilibrium and kinetic control(Gu et al., 2009; Maggi et al., 2008; Pruess, 2005; Xu et al., 2006). The soil hydraulic properties are described by a water tension-saturation model. Water flow and solute transport in liquid and gaseous phases are modeled with the Darcy-Richards' equation, bulk advective mass transport, and Fick's law. Biotic and abiotic reactions follow Michaelis-Menten kinetics, while an arbitrary number of micro-organisms can be modeled using multiple Monod growth kinetics to account for electron donor, acceptor, and inhibitor concentrations.

The reactions responsible for $\mathrm{N}$ transformations are numerous and primarily mediated by several functional groups of microorganisms that extensively inhabit nearsurface soils. These microorganisms can potentially transform $\mathrm{N}$ via multiple pathways (Wrage et al, 2001), and under various conditions of temperature, $\mathrm{pH}$, water content, substrate, and electron acceptor and inhibitor concentrations (Knowles, 1982). The reaction network simulated in TOUGHREACT-N includes $\mathrm{N}$ mineralization and immobilization, biological nitrification (i.e., $\mathrm{NH}_{4}{ }^{+} \rightarrow \mathrm{NO}_{2}{ }^{-} \rightarrow \mathrm{NO}_{3}{ }^{-}$), biological denitrification (i.e., $\mathrm{NO}_{3}{ }^{-} \rightarrow \mathrm{NO}_{2}{ }^{-} \rightarrow \mathrm{NO} \rightarrow \mathrm{N}_{2} \mathrm{O} \rightarrow \mathrm{N}_{2}$ ), dissolved organic $\mathrm{C}$ transport, and chemical $\mathrm{N}$ decomposition (i.e., $\mathrm{HNO}_{2}^{-} \rightarrow \mathrm{NO}$ ) (Figure 1).

\subsection{Model Calibration and Testing}

In the current study, the model was tested against previous observations from a field experiment conducted in La Selva, a biological station of the Organization for Tropical Studies, located in the province of Heredia ( $10^{\circ} 26^{\prime} \mathrm{N} ; 83^{\circ} 58^{\prime} \mathrm{W}, 40 \mathrm{~m}$ approx. elevation above sea level), in the transition zone from the coastal plain to the steep foothills of the Costa Rican Cordillera Central (Nobre et al., 2001). The area was cleared to bare soil for the establishment of the experimental plots. The sandy loam soil is an Andic Fluventic Eutropet and is rich in exchangeable bases. The stainless steel soil-gasphase probes and tensiometers were used for sampling at depths of 2, 5, 10,20, and 40 $\mathrm{cm}$. Three water pulses of $10 \mathrm{~mm}, 10 \mathrm{~mm}$, and $30 \mathrm{~mm}$ were added at day 0 , day 9 , and 
day 16, respectively, of the experiment. The water was sprayed evenly onto the soil over a period of $30 \mathrm{~min}$. For each simulated rain event, measurements were made preceding the additions and then $30 \mathrm{~min}, 2,4,8$, and $24 \mathrm{~h}$, and daily thereafter, until the next rain event or completion of the experiment. The data we used to calibrate TOUGHREACT-N were soil moisture andsoil $\mathrm{N}_{2} \mathrm{O}$ concentration profiles during the 22-day experimental period.

The simulated $1 \mathrm{~m}$ deep one dimensional soil column was discretized with a spatial resolution of $1.0 \mathrm{~cm}$ (Table 2). The soil profile was divided into six soil layers: 0 2.5, 2.5-7.5, 7.5-15, 15-30, 30-50, 50-100 cm. The Rosetta module (Schaap et al., 2001) was applied using the data listed in Table 1. The averaged soil hydraulic parameters (van Genuchten, 1980) are presented in Table 2.

The initial carbon pool fractions and specific decomposition rates for each pool were taken from Li et al. (1992) and were assumed to be constant with depth (see Table 3). The initial organic carbon content and inorganic nitrogen (i.e. $\mathrm{NH}_{4}{ }^{+}$and $\mathrm{NO}_{3}{ }^{-}$) concentrations were taken from the field measurement (Table 1).

The upper boundary for the water flow was defined by time dependent water flow conditions. The evaporation flux at the soil surface was assumed to be constant and set to $2 \mathrm{~mm} \mathrm{day}^{-1}$ (Nobre, et al. 2001). At the bottom of the domain (1 m depth), a Dirchlet boundary (constant water saturation) was imposed (Table 2). Therefore the bottom of the soil profile allowed gravitational drainage of water and chemicals in the water. The atmospheric gaseous partial pressure (p_atm, bar) was imposed as a Dirichlet boundary condition at the top of the soil profile, while zero gaseous concentration was imposed as a Dirichlet boundary at the domain bottom. Surface diffusive fluxes of gases were computed from concentration gradients between the atmosphere and $1.25 \mathrm{~cm}$ soil depth. The $\mathrm{N}$ leaching flux was estimated as the product of aqueous concentrations at $50 \mathrm{~cm}$ soil depth and the simulated water flux.

The biochemical parameters were taken from the literature and calibration (Table 3). Calibration was assisted by trial and error to minimize the difference between observed and simulated $\mathrm{N}_{2} \mathrm{O}$ concentrations. Comparison between model simulations and observations was evaluated by a linear regression approach with determinant coefficients. 


\subsection{Scenario analysis}

To quantify the effect of increased intra-annual rainfall variability on soil $\mathrm{N}$ losses, we imposed variations in precipitation amount, precipitation variability, and soil texture (Table 5). We explored precipitation variability by altering the temporal distribution and size of rainfall events, with two different total precipitation amounts $(1.5$ and $15 \mathrm{~cm}$

month $^{-1}$ ). The modeling exercise based upon high and low precipitation amounts corresponded to humid and arid ecosystems, respectively. In this study, we did not initialize with the different $\mathrm{N}$ levels expected in these two types of ecosystems because trends of $\mathrm{N}$ gas fluxes were relatively insensitive to the initial $\mathrm{N}$ levels (data not shown)

For each of the two total precipitation amounts, the model was run for six different rainfall patterns spread over a 30-day period. For example, for the $15 \mathrm{~cm}$ month ${ }^{1}$ case the forced precipitations were: (1) $1 \mathrm{~cm}$ of rain in 5 hours every 2 days, (2) $1.5 \mathrm{~cm}$ of rain in 5 hours every 3 days, (3) $2.5 \mathrm{~cm}$ of rain in 5 hours every 5 days, (4) $3.75 \mathrm{~cm}$ of rain in 5 hours every 7.5 days, (5) $5 \mathrm{~cm}$ of rain in 5 hours every 10 days, and (6) $7.5 \mathrm{~cm}$ of rain in 5 hours every 15 days. The most frequent rainfall regime (2-day interval) was chosen as the baseline rainfall variability scenario for comparison. The scenario was chosen based on an analysis of precipitation data recorded at the Heredia site during the past 10 years. During the wet season (May - November), the mean monthly precipitation was $30.3 \mathrm{~cm}$ with mean precipitation amount of $2.2 \mathrm{~cm}$ per event and mean interval between precipitation events of 2.2 days. During the dry season (December - March), the mean monthly precipitation was $3.6 \mathrm{~cm}$ with a mean precipitation amount per event of $0.24 \mathrm{~cm}$.

\section{Results}

\subsection{Experimental Data vs. Model Predictions Comparison}

TOUGHREACT-N predicted the time series of soil water saturation profiles well (Figure 2). The water saturation dynamics reflect the effects of each simulated rain event and subsequent drying on soil water saturation. Simulated soil moisture was well correlated with observations $\left(\mathrm{R}^{2}=0.60\right)$. Simulated soil $\mathrm{N}_{2} \mathrm{O}$ concentration predictions also agreed well with measurements $\left(\mathrm{R}^{2}=0.56\right)$ (Figure 3$)$.

\subsection{Soil Moisture Response in the Model Experiments}


In the model experiments with imposed variations in precipitation intensity and frequency, temporal patterns of soil water content (water filled pore space, WFPS) were influenced by increased rainfall variability (Figure 4). The responses varied widely depending on soil type, total water added, and rainfall variability. The clay loam soil had higher WFPS than the sandy loam soil. The 30-day mean soil WFPS for the $15 \mathrm{~cm}$ month $^{-1}$ precipitation scenario was higher in both soil types than that for the $1.5 \mathrm{~cm}$ month $^{-1}$ precipitation scenario. The factor of ten increase in added water resulted in an increase of mean $10 \mathrm{~cm}$ depth WFPS of $21 \%$ and $34 \%$ in the sandy loam and clay loam soils, respectively.

Precipitation variability influenced soil WFPS differently at the two precipitation levels. For the $1.5 \mathrm{~cm} \mathrm{month}^{-1}$ scenario, the monthly-mean soil WFPS increased with increased precipitation variability. For the $15 \mathrm{~cm} \mathrm{month}^{-1}$ scenario, high precipitation variability led to lower mean soil WFPS in sandy loam soil, especially at the shallower soil depths. Over the 30-day simulation period, average WFPS at $10 \mathrm{~cm}$ depth in the sandy loam soil was reduced by $12 \%$ in the highest precipitation variability versus the baseline rainfall simulation. In the clay loam soil, higher precipitation variability resulted in lower soil WFPS in the surface soil layer but higher soil WFPS in the deep layer compared to the baseline variability scenario. We note that the long-term mean (as opposed to the monthly mean) WFPS at depth may be different than the results reported here, since establishment of a steady-cycle WFPS at depth could require much longer simulations.

\subsection{Soil Nitrogen Gas Efflux Response}

Temporal soil $\mathrm{N}$ gaseous dynamics were also strongly affected by increased rainfall variability (Table 5). The sensitivity of $\mathrm{N}$ effluxes to precipitation variability is low at the low precipitation amount $\left(1.5 \mathrm{~cm} \mathrm{month}^{-1}\right)$. For example, cumulative 30-day $\mathrm{N}_{2} \mathrm{O}$ emissions for the 15 day rainfall interval increased only by $11 \%$ and $1 \%$ in the sandy loam and clay loam soils, respectively, compared with the baseline precipitation variability. In contrast, $\mathrm{N}$ loss is sensitive to precipitation variability in the higher

precipitation scenario $\left(15 \mathrm{~cm} \mathrm{month}^{-1}\right)$. For the clay loam soil case, cumulative NO and $\mathrm{N}_{2} \mathrm{O}$ emissions increased with increased precipitation variability. Cumulative $\mathrm{NH}_{3}$ 
emissions also increased significantly with increased precipitation variability for the 15 $\mathrm{cm}$ month ${ }^{-1}$ precipitation scenarios. In contrast, $\mathrm{NH}_{3}$ emissions decreased with increased precipitation variability for the $1.5 \mathrm{~cm} \mathrm{month}^{-1}$ precipitation scenario. For example, $\mathrm{NH}_{3}$ emission increased by $94 \%$ and $139 \%$ in the sand loam and clay loam soils, respectively, compared with the baseline scenario. $\mathrm{NO}$ and $\mathrm{N}_{2} \mathrm{O}$ gaseous fluxes decreased with increased precipitation variability in sandy loam soil (Table 5).

\subsection{Soil Nitrate Leaching Response}

Soil nitrate leachate fluxes were very sensitive to rainfall variability, especially under the high rainfall amount scenario (Table 5). For the $1.5 \mathrm{~cm} \mathrm{month}^{-1}$ scenario, nitrate leaching at $50 \mathrm{~cm}$ soil depth increased by $10 \%$ and $141 \%$ compared with baseline rainfall variability in the sandy loam and clay loam soils, respectively. For the $15 \mathrm{~cm}$

month $^{-1}$ scenario, $\mathrm{N}$ leachate fluxes in both soils increased with precipitation variability (Table 5). High precipitation variability generally led to significantly higher (up to 12 fold) nitrate leaching than under baseline variability.

\subsection{Soil depth-integrated $\mathrm{N}$ turnover rates}

Figures 5 and 6 show oxygen partial pressure and the depth integrated net NO, $\mathrm{N}_{2} \mathrm{O}$, and $\mathrm{NO}_{3}{ }^{-}$production rate (gross production - gross consumption) for the 5- and 15day precipitation intervals in sandy loam and clay loam soils, respectively. In the sandy loam soil, the 5-day precipitation interval treatment induced lower oxygen partial pressure at $10 \mathrm{~cm}$ soil depth than did the 15-day interval precipitation (Figure 5(a)). There were enhanced $\mathrm{NO}$ and $\mathrm{N}_{2} \mathrm{O}$ net production rates associated with the oxygen partial pressure dips caused by precipitation events. Consequently, the 5-day precipitation interval had overall higher soil denitrifier biomass (Figure 5(e)), and higher net production rates of $\mathrm{NO}$ and $\mathrm{N}_{2} \mathrm{O}$ (Figure $5(\mathrm{~b}) \&(\mathrm{c})$ ). The net $\mathrm{NO}_{3}{ }^{-}$production rates of the 5-day precipitation interval were also slightly higher than those of the 15-day precipitation interval (Figure $5(\mathrm{~d})$ ).

The transient $\mathrm{N}$ turnover pattern responded differently to precipitation variability in the clay loam soil. The oxygen partial pressures at $10 \mathrm{~cm}$ depth for both precipitation treatments were very low $(<0.02)$ (Figure 6 (a)). The oxygen partial pressure of the 15- 
day precipitation interval periodically increased during the prolonged period between precipitation events, while the low oxygen persisted for the 5-day precipitation interval. The net $\mathrm{NO}, \mathrm{N}_{2} \mathrm{O}$, and $\mathrm{NO}_{3}{ }^{-}$production rates for 5-day interval treatment dropped below zero for each precipitation event. In contrast, the $\mathrm{N}$ turnover rates for the 15-day interval were always above zero (Figure (b),(c), and (d)).. Consequently, the soil denitrifier biomass (Figure (e)) and overall $\mathrm{N}$ production rates for the 15-day interval were larger than those of the 5-day precipitation interval.

\section{Discussion}

\subsection{Soil moisture response to precipitation variability}

Increases in precipitation intensity with decreased frequency have been projected as a likely scenario under expected future climate change (Easterling et al., 2000). Field experiments have demonstrated that extreme rainfall events, without concurrrent changes in water amounts, could lead to decreases in mean soil water content and increases in soil moisture temporal variability (Knapp et al., 2002).

Consistent with (Knapp et al., 2002), our modeling results showed that high precipitation variability led to lower mean soil water content than the baseline variability for high rainfall amount scenario. However, when the total precipitation amount was low, the high precipitation variability could lead to higher mean soil moisture than the baseline intensity (Figure 4), which was consistent with a previous modeling study (Weng and Luo, 2008). At the high precipitation amount (i.e., $15 \mathrm{~cm} \mathrm{month}^{-1}$ ), the high precipitation variability also increased mean WFPS at $40 \mathrm{~cm}$ depth in the clay loam soil (Figure 4B). The fine textured, high field capacity soil stored rainwater from large precipitation events more effectively. Additionally, more water was stored in deep soil layers under high precipitation variability than that under the baseline condition.

\subsection{Effect of precipitation variability on $\mathrm{N}$ losses}

Our results suggest increased precipitation intensity with reduced frequency will lead to changes in soil $\mathrm{N}$ losses (i.e. $\mathrm{NO}_{3}{ }^{-}$leaching, $\mathrm{NH}_{3}, \mathrm{NO}$ and $\mathrm{N}_{2} \mathrm{O}$ emissions). Because atmospheric $\mathrm{N}_{2} \mathrm{O}$ contributes significantly to the greenhouse effect and climate 
change, the net effect of changes in precipitation on radiative properties of the atmosphere are likely even larger than when just considering the effects of ecosystem C exchanges.

Increases in soil moisture resulted in predicted increases in anaerobic $\mathrm{N}$ cycling. As shown by the simulations from the clay loam soil, when the precipitation amount was high ( $\left.15 \mathrm{~cm} \mathrm{month}^{-1}\right)$, $\mathrm{NO}$ and $\mathrm{N}_{2} \mathrm{O}$ gas efflux at high precipitation variability was higher than at baseline variability (Table 5). However, with the high precipitation amount in the sandy loam soil, high precipitation variability led to lower $\mathrm{NO}$ and $\mathrm{N}_{2} \mathrm{O}$ gas emissions than the baseline variability because of the lower mean soil WFPS. While $\mathrm{NH}_{3}$ efflux always increased with precipitation variability. These results indicated that soil texture strongly regulates effects of precipitation variability on soil moisture content and the $\mathrm{N}$ cycle.

A number of studies have reported dramatic shifts in $\mathrm{NO}$ and $\mathrm{N}_{2} \mathrm{O}$ emissions from soils with changes in soil moisture (Davidson 1992), with NO emissions typically highest under relatively dry conditions and $\mathrm{N}_{2} \mathrm{O}$ emissions increasing with increasing soil moisture content. Our modeling study showed a consistent pattern of NO gas flux increases within a range of approximately $35-60 \%$ WFPS because water stress release stimulated microbial activity (Figure 7A). For soils above field capacity, however, denitrification dominated as the source of $\mathrm{N}$ gases, with $\mathrm{N}_{2} \mathrm{O}$ being the dominant flux between $60 \%$ and $85 \%$ WFPS (Figure 7A). NO gas emissions showed a negative relationship $\left(\mathrm{R}^{2}=0.57\right.$ ) with soil WFPS variance at $10 \mathrm{~cm}$ depth (Figure $7 \mathrm{~B}$ ), suggesting that the effects of precipitation variability on soil water content may be a more important regulator of $\mathrm{NO}$ flux than is mean soil water content. Unlike $\mathrm{NO}$ emissions, $\mathrm{N}_{2} \mathrm{O}$ emissions were poorly correlated $\left(\mathrm{R}^{2}=0.22\right)$ with variance of soil WFPS at $10 \mathrm{~cm}$ depth. Instead, $\mathrm{N}_{2} \mathrm{O}$ emission showed a better correlation $\left(\mathrm{R}^{2}=0.42\right)$ with mean soil WFPS at 10 $\mathrm{cm}$ depth, suggesting mean soil water content was a better indicator of $\mathrm{N}_{2} \mathrm{O}$ flux than was rainfall variability.

We can gain more insight on the contrasting patterns of $\mathrm{N}$ losses in sandy loam and clay loam soil by examining the depth integrated $\mathrm{N}$ turnover rates for the high precipitation amount scenario presented in Figure 5 and 6 . Under more aerobic conditions, such as in the sandy loam soil, soil oxygen content acted as the primary 
controller on soil $\mathrm{N}$ turnover rates. Frequent precipitation (e.g. 5-day interval) facilitated soil denitrifier growth and accelerated $\mathrm{NO}$ and $\mathrm{N}_{2} \mathrm{O}$ production because more frequent precipitation caused more consistent anaerobic conditions than less frequent precipitation (Figure 5). Consequently, the 15-day precipitation interval produced less $\mathrm{N}$ gases than the 5-day precipitation interval. However, much larger $\mathrm{NO}_{3}{ }^{-}$leaching occurred for the 15day precipitation interval due to the lower nitrate reduction rate than in the 5-day precipitation interval in sandy loam soil.

In contrast, under bulk anaerobic conditions, such as in the clay loam soil, soil $\mathrm{NO}_{3}{ }^{-}$, the substrate for denitrification, is most limited because the soil anaerobicity is not favorable to nitrification. As a result, soil nitrate content, rather than soil oxygen content, controlled soil $\mathrm{N}$ turnover rates. The 15 -day precipitation interval produced higher soil $\mathrm{NO}_{3}{ }^{-}$concentration than did the 5-day precipitation interval because the prolonged dry period between rainfall events facilitated soil nitrification. Subsequently, high soil $\mathrm{NO}_{3}{ }^{-}$ induced enhanced $\mathrm{NO}_{3}{ }^{-}$leaching, and the increased growth of soil denitrifier that enhanced $\mathrm{NO}$ and $\mathrm{N}_{2} \mathrm{O}$ production in the 15-day precipitation interval Scenario (Figure 6).

Transport processes also affect the response of $\mathrm{N}$ losses to rainfall variability. For example, for the 5-day precipitation interval, there were significantly higher $\mathrm{NO}$ and $\mathrm{N}_{2} \mathrm{O}$ soil gas concentrations at depth as well as $\mathrm{NO}$ and $\mathrm{N}_{2} \mathrm{O}$ net production rates in the sandy loam subsoil, compared to those of the 15-day precipitation interval (Figures 8 and 9). The high $\mathrm{NO}$ and $\mathrm{N}_{2} \mathrm{O}$ concentrations at depth for the 5-day precipitation interval resulted primarily from $\mathrm{NO}$ and $\mathrm{N}_{2} \mathrm{O}$ production in the topsoil and subsequent transport to depth (Figure 9). The potential storage of $\mathrm{NO}$ and $\mathrm{N}_{2} \mathrm{O}$ in the lower soil profile and gradual diffusion to the surface is important with respect to overall $\mathrm{NO}$ and $\mathrm{N}_{2} \mathrm{O}$ fluxes from soil. $\mathrm{Li}$ et al (2002) also observed $\mathrm{N}_{2} \mathrm{O}$ accumulation in the subsoil and suggested the important role of soil structure in barring the redistribution of gases from lower in the soil profile to the surface. In our study, the subsoil $\mathrm{N}$ gas accumulation is a remnant of short, strong peaks in gas production in the topsoil, and subsequent gaseous diffusion and aqueous advection of gases into the soil column. The lower diffusion rates in the subsoil due to increased water saturation would block further movement of $\mathrm{N}$ gases. The high $\mathrm{NO}$ and $\mathrm{N}_{2} \mathrm{O}$ concentrations in the subsoil may lead to indirect losses of dissolved $\mathrm{NO}$ and $\mathrm{N}_{2} \mathrm{O}$ through drainage water and further denitrification to $\mathrm{N}_{2}$ (for $\mathrm{N}_{2} \mathrm{O}$ ). In this sense, 
the soil water becomes a temporary storage body entrapping $\mathrm{N}$ gases or causing movement of dissolved $\mathrm{N}$ gases (Clough, et al. 2005).

The reduced soil water saturation caused by precipitation also decreases oxygen diffusion down into the soil column, which can facilitate $\mathrm{N}$ reduction processes. Overall, the net effect of precipitation on $\mathrm{N}$ fluxes will depend on the inter-related process of $\mathrm{N}$ gas production, $\mathrm{N}$ and $\mathrm{O}_{2}$ gaseous and aqueous transport in the soil, and the influence of oxygen on $\mathrm{N}$ turnover rates. Our results suggest that the net effect of precipitation will most likely increase $\mathrm{NO}$ and $\mathrm{N}_{2} \mathrm{O}$ production in aerobic soils (often associated with coarse texture), and decrease $\mathrm{NO}$ and $\mathrm{N}_{2} \mathrm{O}$ production in anaerobic soils (often associated with finer texture soils).

\subsection{Implications for ecosystem responses}

The results in this study indicate that ecosystem $\mathrm{N}$ exchanges are expected to have both common and unique responses to more variable rainfall patterns. An important distinction in the response between humid and arid ecosystems to potential climate change is in their soil water content sensitivity to rainfall variability. In arid ecosystems characterized by small rainfall amounts, soils are typically already dry between events, and evaporation from upper soil layers rapidly leads to low soil water availability. We anticipate that this loss would be substantially reduced if a greater amount of rain fell in fewer events, allowing water to move to deeper soil layers less affected by evaporation. Thus, soil water availability to soil biota may be increased with fewer, larger events in arid ecosystems, particularly in more clayey soils. In humid ecosystems with soils that are more often moist, larger events (with constant total amount) would most likely decrease soil water content in coarse-textured soils because longer periods between rainfall events would lead to greater drying of the soil than is currently experienced. While fine-textured soils, especially at depths, would be expected to increase soil water content and dampen the soil moisture variability induced by less frequent large precipitation events due to its increased water-hold capacity.

This study enriched recent modeling studies that have addressed climate change controls on ecosystem responses (Weng and Luo, 2008; Zhou et al., 2008), and

confirmed the conceptual model proposed by Knapp et al (2008) in that precipitation 
variability can influence soil biogeochemical processes either positively or negatively depending on soil and ecosystem types. In fine-textured soils, higher precipitation variability may lead to reduced period of soil anaerobic state and therefore increase the rate of aerobic biogeochemical processes (e.g. decomposition, nitrification). Extended soil drying has been found to increase soil respiration (Jensen et al. 2003) and $\mathrm{N}$ mineralization (Emmett et al. 2004). In this study, prolonged dry condition may accelerate denitrification by releasing the soil substrate (i.e. nitrate) stress. In contrast, increased precipitation variability will result in coarse textured soils experiencing longer period of soil water stress. Microbial-mediated anaerobic transformation (e.g. denitrification) would decrease concurrently. In deed, responses of soil $\mathrm{N}$ cycle to precipitation are especially complex because of its multiple stress states (i.e. aerobic and anaerobic) that regulate $\mathrm{N}$ transformation pathways. This highlights the need of processbased mechanistic understanding to access the effects of various ecosystem attributes in determining the ecosystem responses to rainfall regimes.

\subsection{Implication for Response Sensitivity}

TOUGHREACT-N simulated the largest sensitivity of $\mathrm{N}$ losses to precipitation variability at high precipitation amounts. It appears, therefore, that more studies are needed in humid regimes in terms of understanding sensitivity of the soil $\mathrm{N}$ cycle to precipitation changes. In our study, nitrate leaching was the most sensitive (with respect to precipitation variability) pathway for $\mathrm{N}$ loss. Given that the sandy loam soil had much higher baseline leaching rate (an order of magnitude higher, data not shown), we expect larger absolute increases of $\mathrm{N}$ aqueous losses in coarse textured soils in humid regions.

\section{Summary}

Our intent in this article has been to analyze how the soil $\mathrm{N}$ cycle may be affected by future increased precipitation variability. Despite the importance of the $\mathrm{N}$ cycle to terrestrial ecosystems, the potential consequences of precipitation variability have received minor attention compared with, e.g., the $\mathrm{C}$ cycle. The key finding of our assessment is that soil $\mathrm{N}$ cycling responses to more variable precipitation depend on baseline precipitation amounts and variability and soil texture, so that different 
ecosystems can be expected to respond uniquely to climate change. Since the $\mathrm{N}$ and $\mathrm{C}$ cycles are tightly linked, these responses may lead to unique, and perhaps surprising, interactions with the soil carbon cycle (Austin et al., 2004).

A deeper understanding of the ecological consequences of more extreme intraannual precipitation patterns will also strengthen our knowledge of $\mathrm{N}$ cycle and climate relationships and feedbacks, and will inform emerging Earth system models so that they can more effectively assess this component of climate change effects. The importance of more extreme precipitation patterns relative to, and in combination with, other global change drivers, such as elevated atmosphere $\mathrm{CO}_{2}$ and warming, needs further study. Alterations in rainfall patterns will be accompanied by elevated atmospheric $\mathrm{CO}_{2}$ and other elements of climate change. Elevated $\mathrm{CO}_{2}$ is expected to increase soil moisture availability in many ecosystems through improved plant water use efficiency (Bazzaz, 1996). Only by thorough analysis of soil $\mathrm{N}$ responses with these drivers independently and interactively, can we improve predictions of soil $\mathrm{N}$ cycling in response to climate change.

\section{Appendix A: Model Description}

\section{Soil Moisture Dynamics}

The model numerically simulates variably saturated water flow using Richards' equation;

$$
\frac{\partial \theta}{\partial t}=\frac{\partial}{\partial z}\left[K(\theta)\left(\frac{\partial[\psi(\theta)}{\partial z}+1\right)\right]
$$

where $\theta$ is soil moisture $\left[\mathrm{m}^{3} \mathrm{~m}^{-3}\right]$ and $\psi(\theta)[\mathrm{Pa}]$ and $K(\theta)\left[\mathrm{m} \mathrm{s}^{-1}\right]$ are the water potential and hydraulic conductivity, respectively, computed as functions of soil type according to van Genuchten (1980).

\section{Multiphase Transport}

TOUGHREACT-N simulates chemical transport using a multiphase form of the advection-dispersion-reaction equation to describe chemical advection in the aqueous phase and diffusive transport in the gas and aqueous phases. The gaseous advection resulting from pressure gradient in the soil is unlikely to be important for cumulative 
gaseous efflux and is ignored here. The model conceptualizes the transient mass balance of chemical species in aqueous, gaseous, and solid phases as:

$$
\frac{\partial}{\partial t}\left(\theta_{a} C_{a}+\theta_{g} C_{g}+\rho_{b} C_{s}\right)=\frac{\partial}{\partial z}\left(\theta_{a} D_{a} \frac{\partial C_{a}}{\partial z}+\theta_{g} D_{g} \frac{\partial C_{g}}{\partial z}\right)-\frac{\partial\left(v_{a} C_{a}\right)}{\partial z}+S
$$

where $C_{a}, C_{g}$, and $C_{s}$ are the species concentrations $\left(\mathrm{mol} \mathrm{m}^{-3}\right)$ in the aqueous, gaseous and solid phases, respectively, $\theta_{a}$ and $\theta_{g}$ are the volumetric fractions $\left(\mathrm{m}^{3} \mathrm{~m}^{-3}\right)$ of the aqueous and gaseous phase, respectively, $\rho_{b}$ is the dry bulk density of the solid phase (kg $\left.\mathrm{m}^{-3}\right), v_{a}$ is the volumetric flux of the aqueous phase $\left(\mathrm{m} \mathrm{s}^{-1}\right), S$ is the source/sink term (kg $\mathrm{m}^{-3} \mathrm{~s}^{-1}$ ) as described in Eq.(A5), $t$ is time (s), and $z$ is the spatial coordinate (m). A linear isotherm is used to relate species concentrations in the aqueous and solid phases, while Henry's law is used to relate species concentrations in the aqueous and gaseous phases. $D_{a}$ and $D_{g}$ are the effective diffusion coefficient in the liquid and gaseous phase, respectively $\left(\mathrm{m}^{2} \mathrm{~s}^{-1}\right)$, computed according to (Millington \& Quirk, 1961):

$$
D_{\beta}=\left(\frac{\theta_{\beta}^{7 / 3}}{\theta^{2}}\right) D_{\beta}^{0}
$$

where $\beta$ is the phase index, $\theta$ is porosity, and $D_{\beta}{ }^{0}$ is free solution or gas diffusion coefficient $\left(\mathrm{m}^{2} \mathrm{~s}^{-1}\right)$.

Free gas diffusion coefficients are computed as a function of temperature, pressure, molecular weight, and molecular diameter. Assuming ideal gas behavior, the tracer diffusion coefficient of a gaseous species can be expressed as [Lasag, 1998]:

$$
D_{g}^{0}=\frac{R T}{3 \sqrt{2} \pi P N_{A} d_{m}^{2}} \sqrt{\frac{8 R T}{\pi M}}
$$

Where $D_{g}{ }^{0}$ is the free gaseous diffusion coefficient $\left(\mathrm{m}^{2} \mathrm{~s}^{-1}\right), R$ is molar gas constant, $T$ is temperature (K), $P$ is pressure $\left(\mathrm{kg} \mathrm{m}^{-1} \mathrm{~s}^{-2}\right), N_{A}$ is Avogadro's number, $d_{m}$ is molecular diameter $(\mathrm{m})$, and $\mathrm{M}$ is molecular weight $\left(\mathrm{kg} \mathrm{mol}^{-1}\right)$

\section{Chemical and Biological Reactions}

To represent the geochemical system in TOUGHREACT-N, we selected a set of aqueous primary species (Table 3 ); these species produce secondary species by chemical reactions of aqueous complexation, gas dissolution and exsolution, and solute adsorption and desorption occurring at local equilibrium. 
The concentrations of aqueous complexes can be expressed as functions of the concentrations of basis species:

$$
c_{i}=\frac{\prod_{j} c_{j}^{v i j} \gamma_{j}^{v i j}}{K_{i} \gamma_{i}}
$$

Where $c_{i}$ is molal concentration of the $i$-th aqueous complex, and $c_{j}$ is molal concentration of the $j$-th primary species, $\gamma_{i}$ and $\gamma_{j}$ are thermodynamic activity coefficients which can be calculated from the extended Debye-Huckel equation, and $K_{i}$ is the equilibrium constant. The proton $\mathrm{H}^{+}$exists as a dissolved species, so acid-base reactions can be treated in a manner similar to aqueous complexation reaction. In this way, $\mathrm{H}^{+}$is explicitly modeled by tracing its production, consumption, and transport.

Gas dissolution and exsolution rates are calculated by relating the aqueous concentration of a primary or secondary species $C_{w i}$ to its partial pressure as:

$$
p_{f} \Gamma_{f} K_{f}=\prod_{j} C_{j}^{v_{f_{j}}} \gamma_{j}^{v_{f_{j}}}
$$

Where subscript $f$ is gas index, $p$ is the partial pressure (bar), $\Gamma$ is the gas fugacity coefficient, which equals to one for atmospheric pressure. $V_{f j}$ is the stoichiometric coefficient of the $j$ th primary species in the $f$ th gaseous species, $C$ is molal concentration of the $j$-th species, $\gamma$ is the thermodynamic activity coefficients. $K$ is the equilibrium constant.

Adsorption and desorption of solute species to the solid phase are computed according to linear equilibrium as:

$$
c_{i}=\frac{\prod_{j} c_{j}^{v i j} \gamma_{j}^{v i j}}{K_{i} \gamma_{i}}
$$

Where $K_{i}$ is the equilibrium constant.

\section{The Nitrogen Cycle}

A full description of inorganic $\mathrm{N}$ biogeochemical processes in TOUGHREACT-N can be found in Maggi et al., [2008]. Briefly, four main N-cycle pathways (nitrification, nitrifier denitrification, denitrification, and chemo-denitrification) were implemented to model N- 
losses and their partitioning between gaseous and aqueous phases. The reaction network and transport mechanism used in TOUGHREACT-N is depicted in Figure 1.

\section{Nitrification, Denitrification and Aerobic Respiration}

Multiple-Monod microbial growth and substrate utilization kinetics are used to describe each step of nitrification, denitrification and aerobic respiration:

$$
S_{i}=B_{i} \hat{\mu}_{i} \prod_{k=1}^{N_{m}} \frac{C_{i, k}}{K_{M i, k}+C_{i, k}} \frac{K_{I i}}{K_{I i}+I_{i}} f\left(S_{\theta}\right) g(p H) .
$$

Here, $S_{i}$ is the reaction rate of the $i^{\text {th }}$ aqueous species $\left[\mathrm{mol} \mathrm{m} \mathrm{s}^{-3}\right], B_{i}$ is biomass $\left[\mathrm{molm}^{-3}\right]$, $\hat{\mu}_{i}$ is maximum specific growth constant $\left[\mathrm{s}^{-1}\right], C_{i, k}$ is the concentration of the $k^{\text {th }}$ species

$\left[\mathrm{mol} \mathrm{m} \mathrm{m}^{-3}\right], I_{i}$ is the concentration of the $i^{\text {th }}$ inhibitor $\left[\mathrm{mol} \mathrm{m}{ }^{-3}\right]\left(\right.$ e.g. $\left.\mathrm{O}_{2}\right), K_{M i, k}$ is the $k^{\text {th }}$ Monod half-saturation constant of the $i^{\text {th }}$ species, $N_{m}$ is the number of Monod terms, $K_{I i}$ is $i$ th inhibition constant, $I_{i}$ is $i^{\text {th }}$ inhibitor concentration, and $f\left(S_{\theta}\right)$ and $g(p H)$ are two piecewise linear functions accounting for microbial water and acidity stress. Finally, stoichiometric production or consumption is simulated by multiplying $S_{i}$ by the corresponding stoichiometric coefficients based on reaction equations. Note that dissolved oxygen concentration is explicitly simulated based on the balance between diffusion and consumption from stoichiometric relationships shown in Table 4. Oxygen inhibition effects on denitrification are simulated by introducing an inhibition term: $\frac{K_{I_{i}}}{K_{I i}+I_{i}}$.

We assumed microbial water and acidity stress following the piecewise linear functions as below (Maggi, et al. 2008):

$$
\begin{gathered}
f\left(S_{\theta}\right)=\min \left\{2 S_{\theta}, 1\right\} \\
g(p H)=\left\{\begin{array}{l}
\min \left\{\frac{1}{4} p H-\frac{3}{4},-\frac{1}{4} p H+\frac{11}{4}\right\}, 3<p H<11 \\
0, p H \geq 1 \text { lorpH } \leq 3
\end{array}\right\}
\end{gathered}
$$

\section{Microbial Dynamics}


The dynamics of each microbial biomass $\left(B_{i}\right)$ is assumed to satisfy the Monod equation:

$$
\frac{\partial B_{i}}{\partial t}=\sum_{c} S_{i c} Y_{i c}-\delta_{i} B_{i}
$$

with $Y_{i c}$ the yield coefficients for $B_{i}$ to grow upon the substrate c [ $\left.\mathrm{mg} \mathrm{mol}^{-1}\right], S_{i c}$ as in Eq. (A5) for each substrate $\mathrm{c}$, and $\delta_{i}$ the biomass death rate $\left[\mathrm{s}^{-1}\right]$.

\section{The Carbon Cycle}

TOUGHREACT-N's prediction of soil carbon cycling is based on DNDC's decomposition module ( $\mathrm{Li}$ et al. 1992). Briefly, TOUGHREACT-N models decomposition by dividing the soil carbon into three organic matter pools: residues, microbial biomass, and humus. These pools are further divided into labile and resistant fractions. Decomposition is modeled as a $1^{\text {st }}$ order decay from each of these pools, where the rate constant is a function of the pool's potential decomposition rate, soil temperature, and soil moisture. Soil N cycling is connected to carbon cycles because each transfer of C requires a concurrent transfer of $\mathrm{N}$. The varying $\mathrm{C}: \mathrm{N}$ ratios of the soil pools cause the balance of soil $\mathrm{N}$ mineralization and immobilization. We estimate additions to the soluble $\mathrm{C}$ (DOC) pool from fluxes out of the microbial and humads pools. DOC is later subject to transport processes (e.g., advection and dispersion). Based on the DOC adsorption studies of Jardine et al-(1992), a kinetic dissolution model is used to simulate the adsorption of DOC. In TOUGHREACT-N, DOC is competitively consumed by Ammonium Oxidizer Bacteria (AOB) and Denitrifier (DEN) during denitrification, and by other heterotrophic and aerobic microbes (AER) during respiration, resulting in $\mathrm{CO}_{2}$ production (Figure 1).

\section{Acknowledgement}

This work was supported by Laboratory Directed Research and Development (LDRD) funding from Berkeley Lab, provided by the Director, Office of Science, of the U.S. Department of Energy under Contract No. DE-AC02-05CH11231. The authors also acknowledge James Hunt (University of California, Berkeley) and Curt Oldenburg (Lawrence Berkeley National Laboratory) for making this project possible. Thanks are also given to the two anonymous reviewers whose comments significantly improve our manuscript. 


\section{References}

Aber, J.D., Goodale, C.L., Ollinger, S.V., Smith, M.L., Magill, A.H., Martin, M.E., Hallett, R.A., \& Stoddard, J.L. (2003). Is nitrogen deposition altering the nitrogen status of northeastern forests? Bioscience 53, 375-389.

Aranibar, J.N., Otter, L., Macko, S.A., Feral, C.J.W., Epstein, H.E., Dowty, P.R., Eckardt, F., Shugart, H.H., \& Swap, R.J. (2004). Nitrogen cycling in the soilplant system along a precipitation gradient in the Kalahari sands. Global Change Biology 10, 359-373.

Austin, A.T., Yahdjian, L., Stark, J.M., Belnap, J., Porporato, A., Norton, U., Ravetta, D.A., \& Schaeffer, S.M. (2004). Water pulses and biogeochemical cycles in arid and semiarid ecosystems. Oecologia 141, 221-235.

Bazzaz, F.A. (1996). Plants in changing environments: Linking physiological, population, and community ecology. Plants in changing environments: Linking physiological, population, and community ecology: Cambridge University Press; Cambridge University Press, p. ix $+320 p$.

Bollmann, A., \& Conrad, R. (1998). Influence of O-2 availability on NO and N2O release by nitrification and denitrification in soils. Global Change Biology 4, 387-396.

Brooks, P.D., Campbell, D.H., Tonnessen, K.A., \& Heuer, K. (1999). Natural variability in $\mathrm{N}$ export from headwater catchments: snow cover controls on ecosystem $\mathrm{N}$ retention. Hydrological Processes 13, 2191-2201.

Corre, M.D., Schnabel, R.R., \& Stout, W.L. (2002). Spatial and seasonal variation of gross nitrogen transformations and microbial biomass in a Northeastern US grassland. Soil Biology \& Biochemistry 34, 445-457.

Easterling, D.R., Meehl, G.A., Parmesan, C., Changnon, S.A., Karl, T.R., \& Mearns, L.O. (2000). Climate extremes: Observations, modeling, and impacts. Science 289, 2068-2074.

Emmett BA, Beier C, Estiarte M, Tietema A, Kristensen HL, Williams D, Penuelas J, Schmidt IK, Sowerby A. 2004. The response of soil processes to climate change: Results from manipulation studies across an environmental gradient.Ecosystems 7:625-637.

Galloway, J.N., Aber, J.D., Erisman, J.W., Seitzinger, S.P., Howarth, R.W., Cowling, E.B., \& Cosby, B.J. (2003). The nitrogen cascade. Bioscience 53, 341-356.

Galloway, J.N., Townsend, A.R., Erisman, J.W., Bekunda, M., Cai, Z.C., Freney, J.R., Martinelli, L.A., Seitzinger, S.P., \& Sutton, M.A. (2008). Transformation of the nitrogen cycle: Recent trends, questions, and potential solutions. Science 320, 889-892.

Gerten, D., Luo, Y., Le Maire, G., Parton, W.J., Keough, C., Weng, E., Beier, C., Ciais, P., Cramer, W., Dukes, J.S., Hanson, P.J., Knapp, A.A.K., Linder, S., Nepstad, D., Rustad, L., \& Sowerby, A. (2008). Modelled effects of precipitation on ecosystem carbon and water dynamics in different climatic zones. Global Change Biology 14, 2365-2379.

Gu, C., Maggi, F., Riley, W.J., Hornberger, G.M., Xu, T., Oldenburg, C.M., Spycher, N., Miller, N.L., Venterea, R.T., \& Steefel, C. (2009). Aqeuous and Gaseous Nitrogen Losses Induced by Fertilizer Application. Journal of Geophysical Research-Biogeoscience 114, doi:10.1029/2008JG000788. 
Harper, C.W., Blair, J.M., Fay, P.A., Knapp, A.K., \& Carlisle, J.D. (2005). Increased rainfall variability and reduced rainfall amount decreases soil CO2 flux in a grassland ecosystem. Global Change Biology 11, 322-334.

Hedin, L.O., von Fischer, J.C., Ostrom, N.E., Kennedy, B.P., Brown, M.G., \& Robertson, G.P. (1998). Thermodynamic constraints on nitrogen transformations and other biogeochemical processes at soil-stream interfaces. Ecology 79, 684703.

IPCC. (2001). Intergovernmental Panel on Climate Change Cambridge: Cambridge University Press.

IPCC. (2007). Intergovernmental Panel on Climate Change Cambridge: Cambridge University Press.

Jardine, P.M., Dunnivant, F.M., Selim, H.M., \& McCarthy, J.F. (1992). Comparison of Models for Describing the Transport of Dissolved Organic-Carbon in Aquifer Columns. Soil Science Society of America Journal 56, 393-401.

Jensen K, Beier C, Michelsen A, Emmett BA. 2003. Effects of experimental drought on microbial processes in two temerate heathlands at constrasting water conditions. Applied Soil Ecology 24: 165-176.

Knapp, A.K., Beier, C., Briske, D.D., Classen, A.T., Luo, Y., Reichstein, M., Smith, M.D., Smith, S.D., Bell, J.E., Fay, P.A., Heisler, J.L., Leavitt, S.W., Sherry, R., Smith, B., \& Weng, E. (2008). Consequences of More Extreme Precipitation Regimes for Terrestrial Ecosystems. Bioscience 58, 811-821.

Knapp, A.K., Fay, P.A., Blair, J.M., Collins, S.L., Smith, M.D., Carlisle, J.D., Harper, C.W., Danner, B.T., Lett, M.S., \& McCarron, J.K. (2002). Rainfall variability, carbon cycling, and plant species diversity in a mesic grassland. Science 298, 2202-2205.

Knowles, R. (1982). DENITRIFICATION. Microbiological Reviews 46, 43-70.

Li, C.S., Frolking, S., \& Frolking, T.A. (1992). A Model of Nitrous-Oxide Evolution from Soil Driven by Rainfall Events .1. Model Structure and Sensitivity. Journal of Geophysical Research-Atmospheres 97, 9759-9776.

Lowrance, R., Altier, L.S., Newbold, J.D., Schnabel, R.R., Groffman, P.M., Denver, J.M., Correll, D.L., Gilliam, J.W., Robinson, J.L., Brinsfield, R.B., Staver, K.W., Lucas, W., \& Todd, A.H. (1997). Water quality functions of Riparian forest buffers in Chesapeake Bay watersheds. Environmental Management 21, 687-712. Maggi, F., Gu, C., Riley, W.J., Hornberger, G.M., Venterea, R.T., Xu, T., Spycher, N., Steefel, C., Miller, N.L., \& Oldenburg, C.M. (2008). A mechanistic treatment of the dominant soil nitrogen cycling processes: Model development, testing, and application. Journal of Geophysical Research-Biogeosciences 113.

McTaggart, I.P., Akiyama, H., Tsuruta, H., \& Ball, B.C. (2002). Influence of soil physical properties, fertiliser type and moisture tension on $\mathrm{N}_{2} \mathrm{O}$ and $\mathrm{NO}$ emissions from nearly saturated Japanese upland soils. Nutrient Cycling in Agroecosystems 63, 207-217.

Millington, R.J., \& Quirk, J.P. (1961). Permeability of porous solids. Trans.Faraday Soc. $15,1200-1207$.

Nobre, A.D., Keller, M., Crill, P.M., \& Harriss, R.C. (2001). Short-term nitrous oxide profile dynamics and emissions response to water, nitrogen and carbon additions in two tropical soils. Biology and Fertility of Soils 34, 363-373. 
Power, J.F., \& Schepers, J.S. (1989). NITRATE CONTAMINATION OF GROUNDWATER IN NORTH-AMERICA. Agriculture Ecosystems \& Environment 26, 165-187.

Pruess, K. (2005). The TOUGH codes - A family of simulation tools for multiphase flow and transport processes in permeable media. Vadose Zone Journal 3, 738746.

Riley, W.J., \& Matson, P.A. (2000). NLOSS: A mechanistic model of denitrified $\mathrm{N}_{2} \mathrm{O}$ and $\mathrm{N}_{2}$ evolution from soil. Soil Science 165, 237-249.

Schaap, M.G., Leij,F.J., van Genuchten,M.Th., 2001. Rosetta: a computer program for estimating soil hydraulic parameters with hierarchiacal pedotransfer functions. J. Hydrol. 251, 163-176

Skiba, U., Fowler, D., \& Smith, K.A. (1997). Nitric oxide emissions from agricultural soils in temperate and tropical climates: sources, controls and mitigation options. Nutrient Cycling in Agroecosystems 48, 139-153.

Spalding, R.F., \& Exner, M.E. (1993). OCCURRENCE OF NITRATE IN GROUNDWATER - A REVIEW. Amer Soc Agronomy, pp. 392-402.

Squillace, P.J., Scott, J.C., Moran, M.J., Nolan, B.T., \& Kolpin, D.W. (2002). VOCs, pesticides, nitrate, and their mixtures in groundwater used for drinking water in the United States. Environmental Science \& Technology 36, 1923-1930.

vanderWeerden, T.J., \& Jarvis, S.C. (1997). Ammonia emission factors for N fertilizers applied to two contrasting grassland soils. Environmental Pollution 95, 205-211.

van Genuchten, M.Th., 1980. A closed-form equation for predicting the hydraulic conductivity of unsaturated soils. Soil Sci. Soc.Am.J. 44, 892-898.

Weng, E.S., \& Luo, Y.Q. (2008). Soil hydrological properties regulate grassland ecosystem responses to multifactor global change: A modeling analysis. Journal of Geophysical Research-Biogeosciences 113, 16.

Wrage, N., Velthof, G.L., van Beusichem, M.L., \& Oenema, O. (2001). Role of nitrifier denitrification in the production of nitrous oxide. Soil Biology \& Biochemistry 33, 1723-1732.

Xu, T.F., Sonnenthal, E., Spycher, N., \& Pruess, K. (2006). TOUGHREACT - A simulation program for non-isothermal multiphase reactive geochemical transport in variably saturated geologic media: Applications to geothermal injectivity and $\mathrm{CO} 2$ geological sequestration. Computers \& Geosciences 32, 145 165.

Zhou, X.H., Weng, E.S., \& Luo, Y.Q. (2008). Modeling patterns of nonlinearity in ecosystem responses to temperature, $\mathrm{CO} 2$, and precipitation changes. Ecological Applications 18, 453-466. 
Table

Table 1. Some physical and chemical properties of the studied soils (Nobre et al. 2000)

Table 2. Physical parameters used for the unsaturated-saturated flow system

Table 3 Equilibrium reactions involved in soil $\mathrm{N}$ cycle (Maggi, et al., 2008)

Table 4 Kinetic reactions and parameters of soil $\mathrm{N}$ cycle

Table 5 Sensitivity of $\mathrm{NO}, \mathrm{N}_{2} \mathrm{O}, \mathrm{NH}_{3}$, and $\mathrm{NO}_{3}{ }^{-}$fluxes to varying precipitation variability and amount 
Figures

Figure 1. Schematic representation of the chain of biochemical nitrification and denitrification reactions (left side), microbial respiration (right side), and soil $\mathrm{N}$ mineralization and immobilization (bottom). Mineral, liquid, and gaseous domains are separated by dashed lines. $\mathrm{AOB}, \mathrm{NOB}, \mathrm{DEN}$, and AER stand for ammonia oxidizing bacteria, nitrite oxidizing bacteria, denitrifying bacteria, and aerobic bacteria, respectively. DOC represents dissolved organic carbon (modified from Maggi, et.al., (2008)).

Figure 2. Observed and simulated soil water saturation $\left(\mathrm{S}_{\theta}\right)$ profiles at the Costa Rican Cordillera Central site in response to three water additions at days 0,9 , and.

Figure 3. Observed and simulated soil $\mathrm{N}_{2} \mathrm{O}$ partial pressure (bar) profiles at the Costa Rican Cordillera Central site in response to three water additions on days 0, 9, and 16.

Figure 4. 30-day mean water filled pore space (WFPS) at 10 and $40 \mathrm{~cm}$ depth for A) sandy loam and B) clay loam soils as a function of rainfall intervals. WFPS ${ }^{1}$ and WFPS ${ }^{2}$ represent WFPS from $1.5 \mathrm{~cm} \mathrm{month}^{-1}$ scenario and $15 \mathrm{~cm} \mathrm{month}^{-1}$ scenario, respectively.

Figure 5. Time series of (a) soil oxygen partial pressure at $10 \mathrm{~cm}$ depth and depth integrated (b) net $\mathrm{N}_{2} \mathrm{O}$, (c) $\mathrm{NO}$, (d) $\mathrm{NO}_{3}{ }^{-}$production rates, and (e) denitrifier (DEN) concentration from sandy loam soil for $5 \mathrm{~d}$ and $15 \mathrm{~d}$ precipitation intervals.

Figure 6. Time series of (a) soil oxygen partial pressure at $10 \mathrm{~cm}$ depth and depth integrated net (b) $\mathrm{N}_{2} \mathrm{O}$, (c) $\mathrm{NO}$, (d) $\mathrm{NO}_{3}{ }^{-}$production rates, and (e) denitrifier (DEN) concentrationfrom clay loam soil for $5 \mathrm{~d}$ and $15 \mathrm{~d}$ precipitation intervals.

Figure 7. Relationships between $\mathrm{NO}$ and $\mathrm{N}_{2} \mathrm{O}$ fluxes and (A) mean soil WFPS at $10 \mathrm{~cm}$ depth and (B) variance of soil WFPS at $10 \mathrm{~cm}$ depth. These relationships are based on all simulation results combining three treatment variables.

Figure 8. Spatiotemporal dynamics of $\mathrm{NO}$ and $\mathrm{N}_{2} \mathrm{O}$ partial pressure in the sandy loam soil with 15-day vs. 5-day at $15 \mathrm{~cm} \mathrm{month}^{-1}$ precipitation scenario.

Figure 9. Spatiotemporal dynamics of net production rates of $\mathrm{NO}$ and $\mathrm{N}_{2} \mathrm{O}$ in the sandy loam soil with 15-day vs. 5 -day at $15 \mathrm{~cm} \mathrm{month}^{-1}$ precipitation scenario. 
Table 1. Some physical and chemical properties of the studied soils (Nobre et al. 2001)

\begin{tabular}{|c|c|c|c|c|c|c|c|c|c|}
\hline Depth(cm) & Bulk Density $\left(\mathrm{gcm}^{-3}\right)$ & Sand (\%) & Silt (\%) & Clay (\%) & pH & $\mathrm{NO}_{3}^{-}\left(\mathrm{mgNkg}^{-1}\right)$ & $\mathrm{NH}_{4}^{+}\left(\mathrm{mgNkg}^{-1}\right)$ & Total N (\%) & Total C(\%) \\
\hline $0-2.5$ & 0.7 & 66.5 & 26.5 & 7.0 & 6.4 & 19.6 & 12.6 & 0.4 & 3.9 \\
\hline $2.5-7.5$ & 0.8 & 66.5 & 21.5 & 12.0 & 6.5 & 20.8 & 7.8 & 0.2 & 2.4 \\
\hline $7.5-15$ & 0.9 & 69.5 & 18.5 & 12.0 & 6.6 & 5.8 & 1.4 & 0.2 & 2.0 \\
\hline $15-30$ & 1.0 & 70.0 & 15.0 & 15.0 & 6.5 & 1.7 & 0.9 & 0.2 & 2.0 \\
\hline $30-50$ & 1.0 & 66.5 & 23.5 & 10.0 & 6.4 & 0.5 & 0.2 & 0.1 & 0.7 \\
\hline $50-100 *$ & 1.0 & 66.5 & 23.5 & 10.0 & 6.4 & 0.5 & 0.2 & 0.1 & 0.7 \\
\hline
\end{tabular}

*The values were taken from the $30-50 \mathrm{~cm}$ depth due to the lack of measurement below $50 \mathrm{~cm}$ depth

4 
1 Table 2. Physical parameters used for the unsaturated-saturated flow system.

2

\begin{tabular}{|c|c|}
\hline Parameter & Value \\
\hline Depth $(\mathrm{cm})$ & 100 \\
\hline Grid size $(\mathrm{cm})$ & 1.0 \\
\hline $\begin{array}{c}\mathrm{O}_{2}, \mathrm{CO}_{2}, \mathrm{NH}_{3}, \mathrm{NO}, \mathrm{N}_{2} \mathrm{O} \text {, and } \mathrm{N}_{2} \text { partial } \\
\text { pressure in atmosphere (bar) }\end{array}$ & $0.2,4 \times 10^{-4}, 0,0,0,0$ \\
\hline Permeability $\left(\mathrm{m}^{2}\right)$ & $1.0 \times 10^{-9}$ \\
\hline Aqueous diffusion coefficient $\left(\mathrm{m}^{2} \mathrm{~s}^{-1}\right)$ & 0.3 \\
\hline Porosity & \\
\hline $\begin{array}{c}\text { Relative permeability and capillary } \\
\text { pressure (van Genuchten curves, } 1980)\end{array}$ & 0.42 \\
\hline$\lambda$ & 0.1 \\
\hline $\mathrm{S}_{\mathrm{lr}}$ & 1.0 \\
\hline $\mathrm{S}_{\mathrm{ls}}$ & $2.43 \times 10^{3}$ \\
\hline $\mathrm{P}_{0}(\mathrm{~Pa})$ & \\
\hline
\end{tabular}


1 Table 3 Equilibrium Reactions involved in soil N cycle (Maggi, et al., 2008)

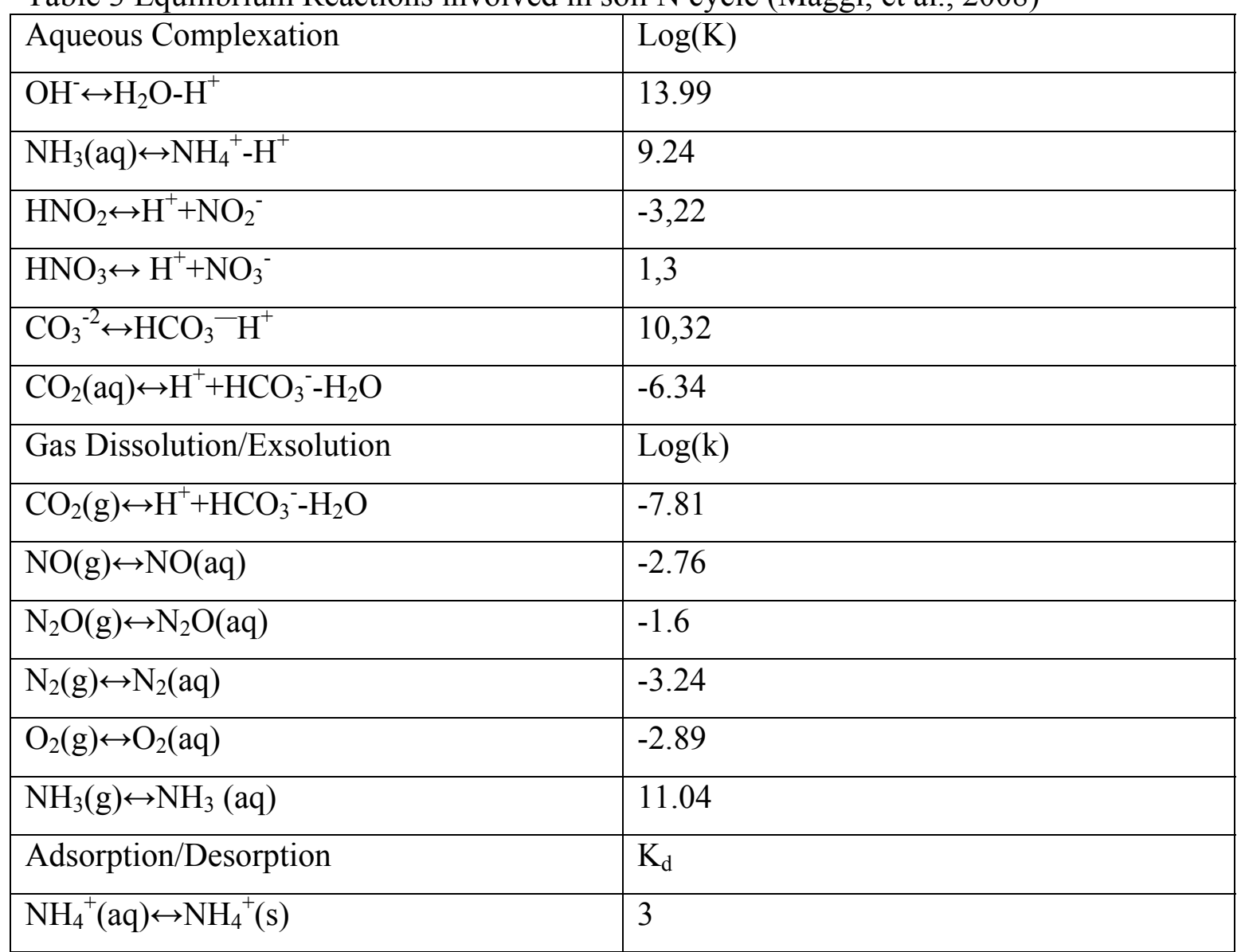


Table 4 Kinetic reactions and parameters of soil $\mathrm{N}$ cycle

\begin{tabular}{|c|c|c|c|c|c|c|}
\hline Microbial Reaction & Microbe & $\hat{\mu}_{i}\left(\mathrm{~s}^{-1}\right)$ & $K_{c}\left(\mathrm{molL}^{-1}\right)$ & $K_{e}\left(\mathrm{molL}^{-1}\right)$ & $K_{l}\left(\mathrm{molL}^{-1}\right)$ & $Y(\mathrm{kgC} / \mathrm{kgN})$ \\
\hline $\mathrm{NH}_{4}^{+}+3 / 2 \mathrm{O}_{2}(\mathrm{aq}) \rightarrow \mathrm{NO}_{2}^{-}+\mathrm{H}_{2} \mathrm{O}+2 \mathrm{H}^{+}$ & $\mathrm{AOB}$ & $5.22 \times 10^{-5}$ & $1.48 \times 10^{-3}$ & $2.41 \times 10^{-5}$ & - & 0.56 \\
\hline $\mathrm{NO}_{2}^{-}+1 / 2 \mathrm{O}_{2}(\mathrm{aq}) \rightarrow \mathrm{NO}_{3}^{-}$ & NOB & $5.23 \times 10^{-5}$ & $1.48 \times 10^{-3}$ & $2.41 \times 10^{-5}$ & - & 0.52 \\
\hline $2 \mathrm{NO}_{3}{ }^{-}+\mathrm{CH}_{2} \mathrm{O} \rightarrow 2 \mathrm{NO}_{2}^{-}+\mathrm{CO}_{2}(\mathrm{aq})+\mathrm{H}_{2} \mathrm{O}$ & DEN & $1.80 \times 10^{-4}$ & $8.33 \times 10^{-4}$ & $1.13 \times 10^{-3}$ & $2.52 \times 10^{-5}$ & 0.401 \\
\hline \multirow[t]{2}{*}{$4 \mathrm{NO}_{2}{ }^{-}+\mathrm{CH}_{2} \mathrm{O}+4 \mathrm{H}^{+} \rightarrow 4 \mathrm{NO}(\mathrm{aq})+\mathrm{CO}_{2}(\mathrm{aq})+3 \mathrm{H}_{2} \mathrm{O}$} & $\overline{\mathrm{DEN}}$ & $1.80 \times 10^{-4}$ & $8.33 \times 10^{-4}$ & $1.13 \times 10^{-3}$ & $2.52 \times 10^{-5}$ & 0.428 \\
\hline & $\mathrm{AOB}$ & $1.82 \times 10^{-4}$ & $8.33 \times 10^{-4}$ & $1.13 \times 10^{-3}$ & $6.15 \times 10^{-5}$ & 0.428 \\
\hline \multirow[t]{2}{*}{$8 \mathrm{NO}(\mathrm{aq})+2 \mathrm{CH}_{2} \mathrm{O} \rightarrow 4 \mathrm{~N}_{2} \mathrm{O}(\mathrm{aq})+2 \mathrm{CO}_{2}(\mathrm{aq})+2 \mathrm{H}_{2} \mathrm{O}$} & DEN & $9.07 \times 10^{-5}$ & $8.33 \times 10^{-4}$ & $1.13 \times 10^{-3}$ & $2.52 \times 10^{-5}$ & 0.4 \\
\hline & AOB & $1.76 \times 10^{-4}$ & $8.33 \times 10^{-4}$ & $1.13 \times 10^{-3}$ & $6.15 \times 10^{-5}$ & 0.4 \\
\hline \multirow[t]{2}{*}{$4 \mathrm{~N}_{2} \mathrm{O}(\mathrm{aq})+2 \mathrm{CH}_{2} \mathrm{O} \rightarrow 4 \mathrm{~N}_{2}(\mathrm{aq})+2 \mathrm{CO}_{2}(\mathrm{aq})+2 \mathrm{H}_{2} \mathrm{O}$} & $\overline{\mathrm{DEN}}$ & $9.02 \times 10^{-5}$ & $8.33 \times 10^{-4}$ & $1.13 \times 10^{-3}$ & $2.52 \times 10^{-5}$ & 0.151 \\
\hline & $\mathrm{AOB}$ & $9.28 \times 10^{-5}$ & $8.33 \times 10^{-4}$ & $1.13 \times 10^{-3}$ & $2.52 \times 10^{-5}$ & 0.151 \\
\hline $\mathrm{CH}_{2} \mathrm{O}+\mathrm{O}_{2}(\mathrm{aq}) \rightarrow \mathrm{CO}_{2}(\mathrm{aq})+\mathrm{H}_{2} \mathrm{O}$ & DEN & $2.06 \times 10^{-4}$ & $8.33 \times 10^{-4}$ & $1.13 \times 10^{-3}$ & - & $0.503(\mathrm{kgC} / \mathrm{kgC})$ \\
\hline Non-microbial Reaction & \multicolumn{6}{|c|}{$1^{\text {st }}$ order reaction rate $\left(\mathrm{s}^{-1}\right)$} \\
\hline $3 \mathrm{NO}_{2}^{-}+\mathrm{H}^{+} \rightarrow \mathrm{H}_{2} \mathrm{O}+\mathrm{NO}_{3}^{-}+2 \mathrm{NO}(\mathrm{aq})$ & \multicolumn{6}{|c|}{$-4.08 \times 10^{-4}$} \\
\hline
\end{tabular}


1 Table 5 Sensitivity of $\mathrm{NO}, \mathrm{N}_{2} \mathrm{O}, \mathrm{NH}_{3}$, and $\mathrm{NO}_{3}{ }^{-}$fluxes to varying precipitation variability

2 and amount

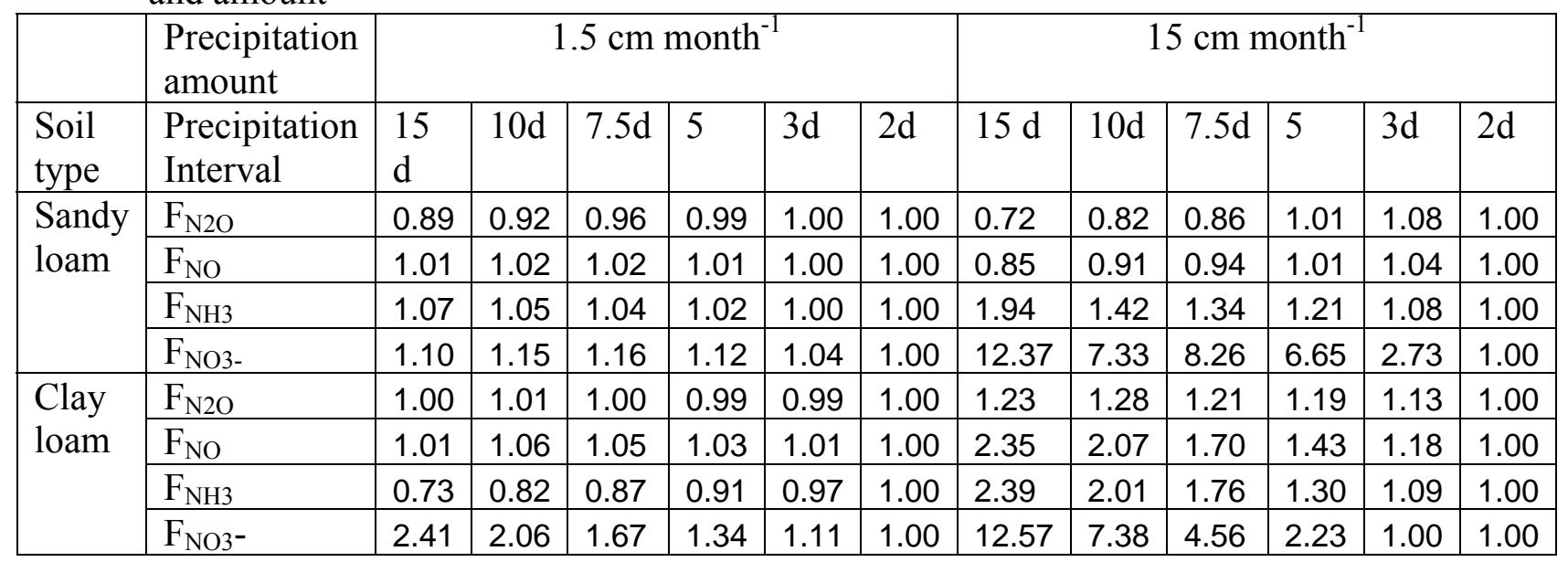




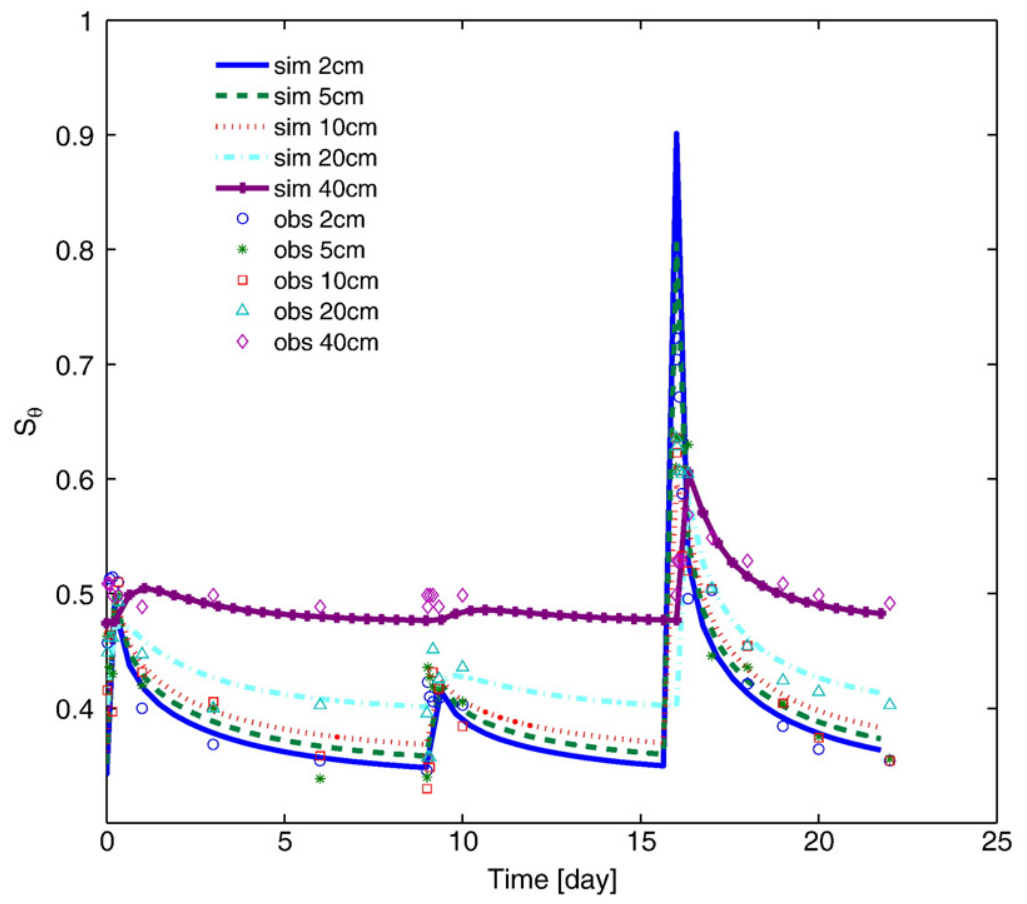

Fig. 2. Observed and simulated soil water saturation $\left(S_{\theta}\right)$ profiles at the Costa Rican Cordillera Central site in response to three water additions at days 0,9 , and 16 . 


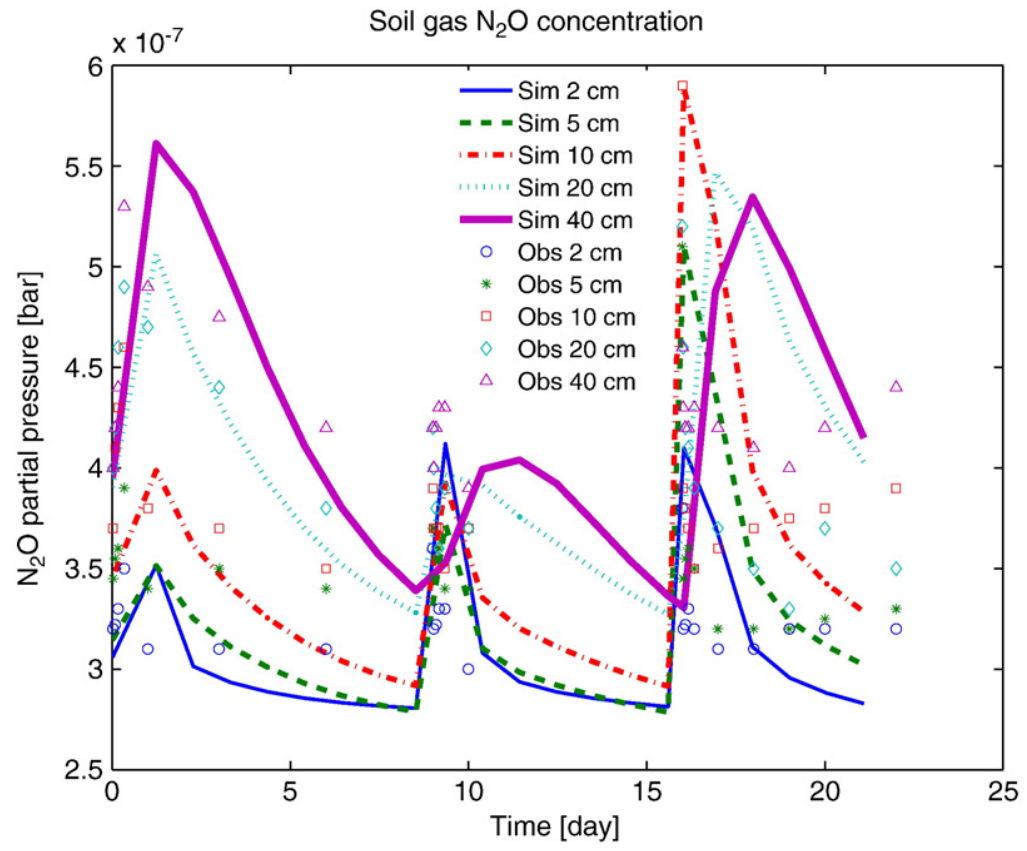

Fig. 3. Observed and simulated soil $\mathrm{N}_{2} \mathrm{O}$ partial pressure (bar) profiles at the Costa Rican Cordillera Central site in response to three water additions on days 0 , 9 , and 16 .

concurrent changes in water amounts, could lead to decreases in mean soil water content and increases in soil moisture temporal variability (Knapp et al., 2002).

Consistent with Knapp et al. (2002), our modeling results showed that high precipitation variability led to lower mean soil water content than the baseline variability for high rainfall amount scenario. However, when the total precipitation amount was low, the high precipitation variability could lead to higher mean soil moisture than the baseline intensity (Fig. 4), which was consistent with a previous modeling study
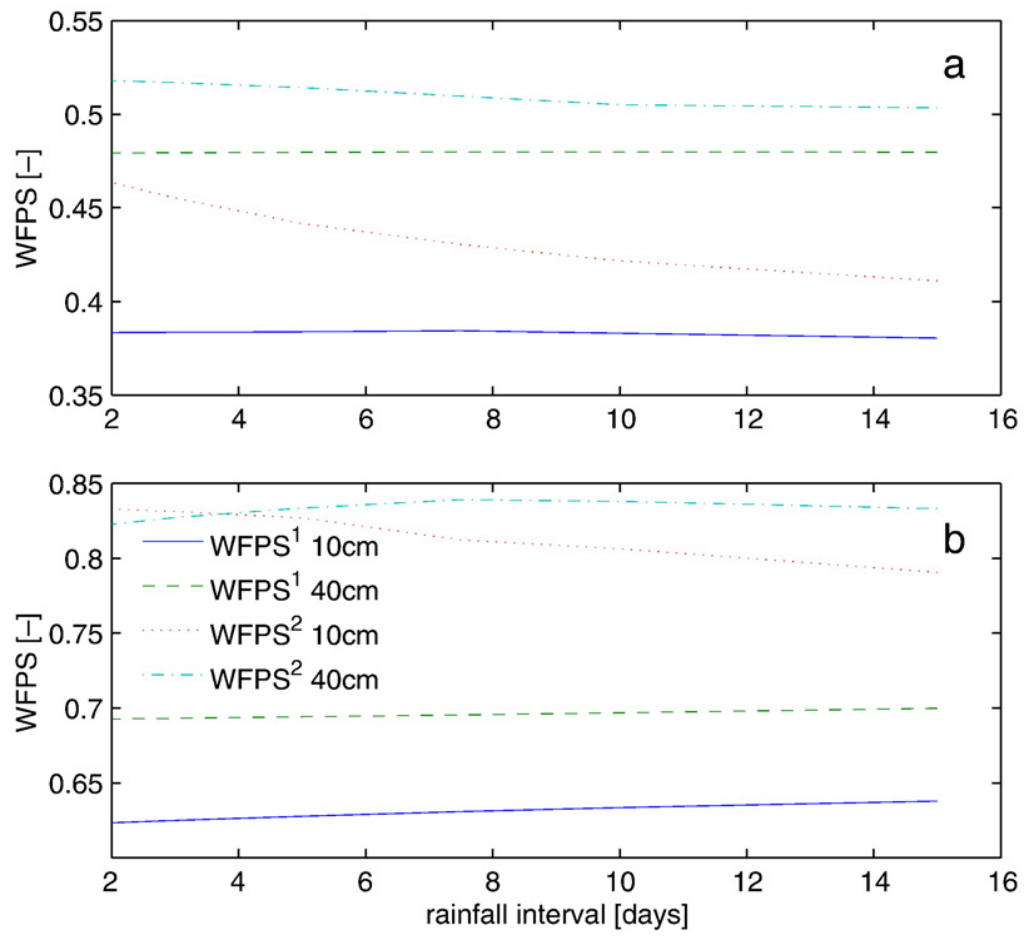

Fig. 4. 30-day mean water filled pore space (WFPS) at 10 and $40 \mathrm{~cm}$ depth for (a) sandy loam and (b) clay loam soils as a function of rainfall intervals. WFPS ${ }^{1}$ and WFPS ${ }^{2}$ represent WFPS from $1.5 \mathrm{~cm}$ month $^{-1}$ scenario and $15 \mathrm{~cm} \mathrm{month}^{-1}$ scenario, respectively. 

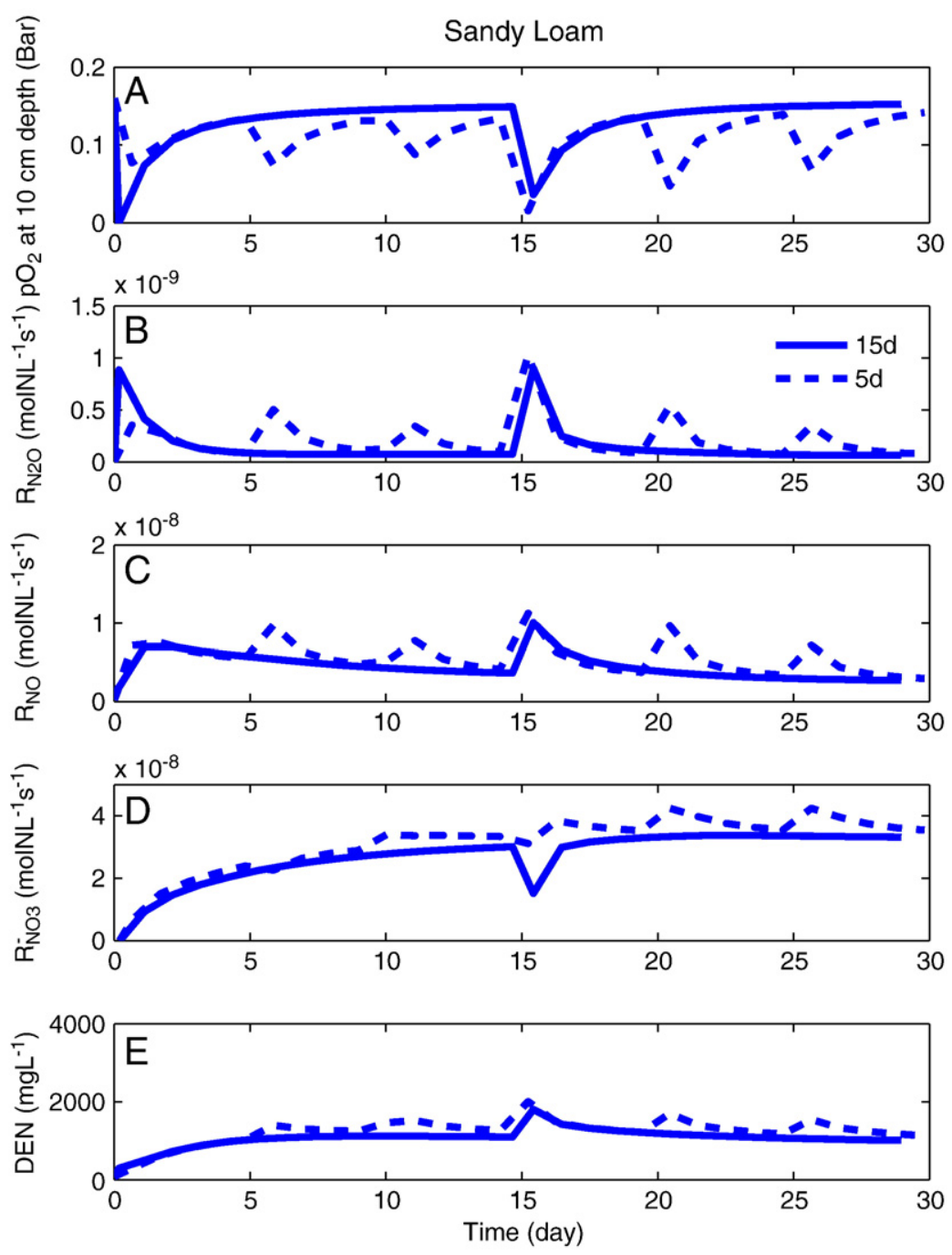

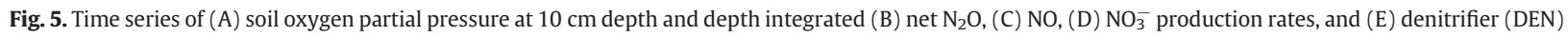
concentration from sandy loam soil for 5-day and 15-day precipitation intervals. 

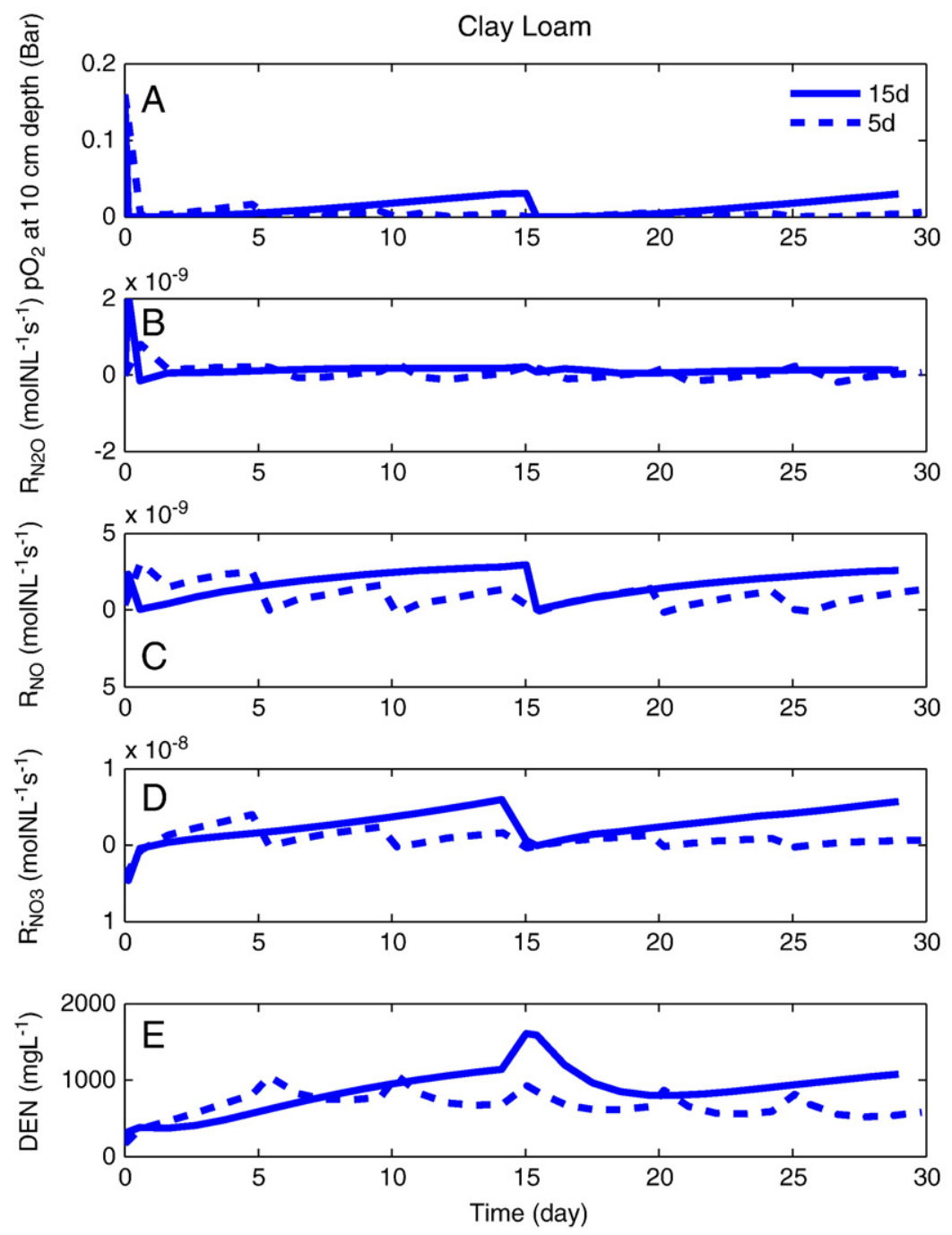

Fig. 6. Time series of (A) soil oxygen partial pressure at $10 \mathrm{~cm}$ depth and depth integrated net (B) $\mathrm{N}_{2} \mathrm{O},(\mathrm{C}) \mathrm{NO}$, (D) $\mathrm{NO}_{3}^{-}$production rates, and (E) denitrifier (DEN) concentration from clay loam soil for 5-day and 15-day precipitation intervals. 

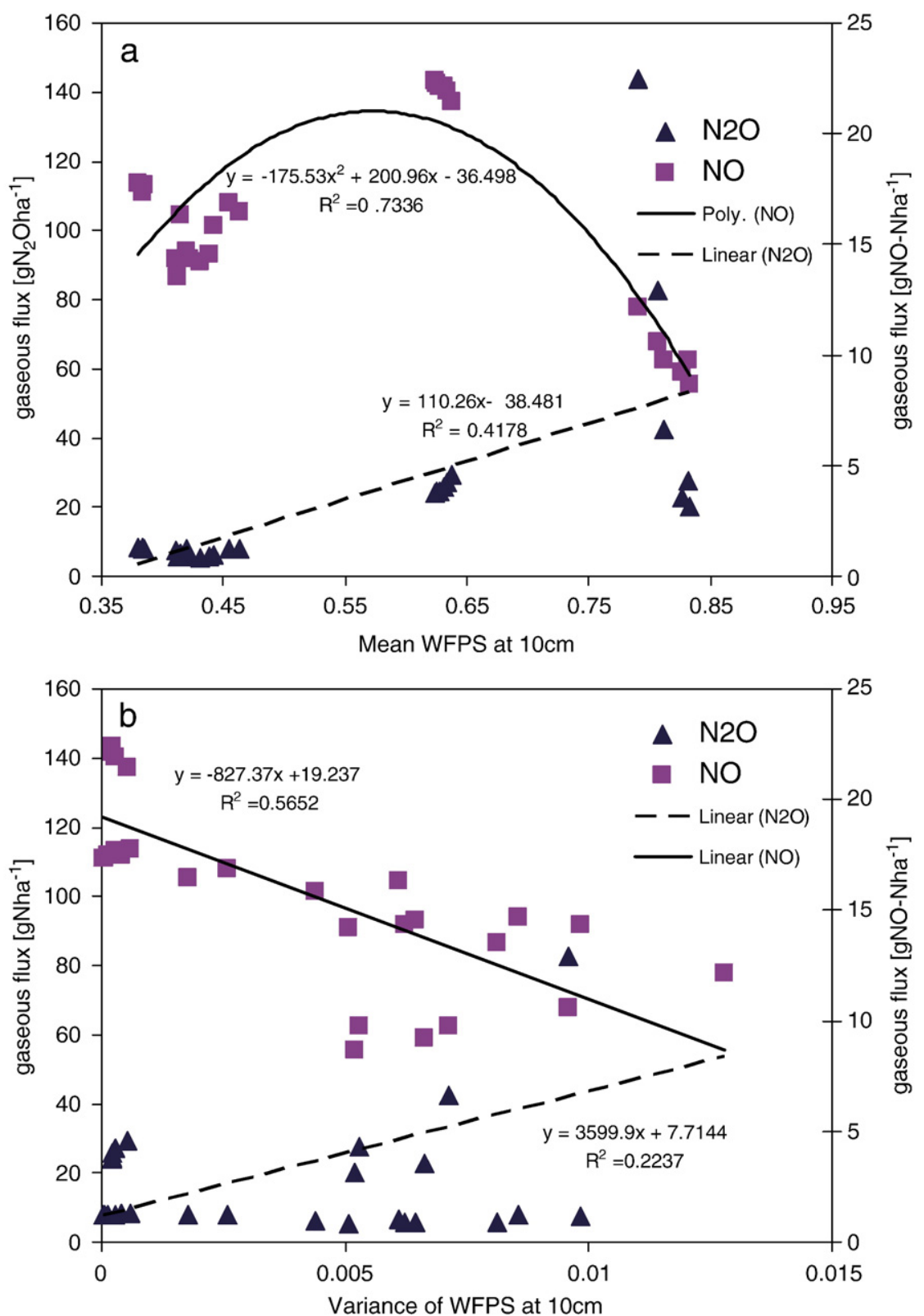

Fig. 7. Relationships between $\mathrm{NO}$ and $\mathrm{N}_{2} \mathrm{O}$ fluxes and (a) mean soil WFPS at $10 \mathrm{~cm}$ depth and (b) variance of soil WFPS at $10 \mathrm{~cm}$ depth. These relationships are based on all simulation results combining three treatment variables. 

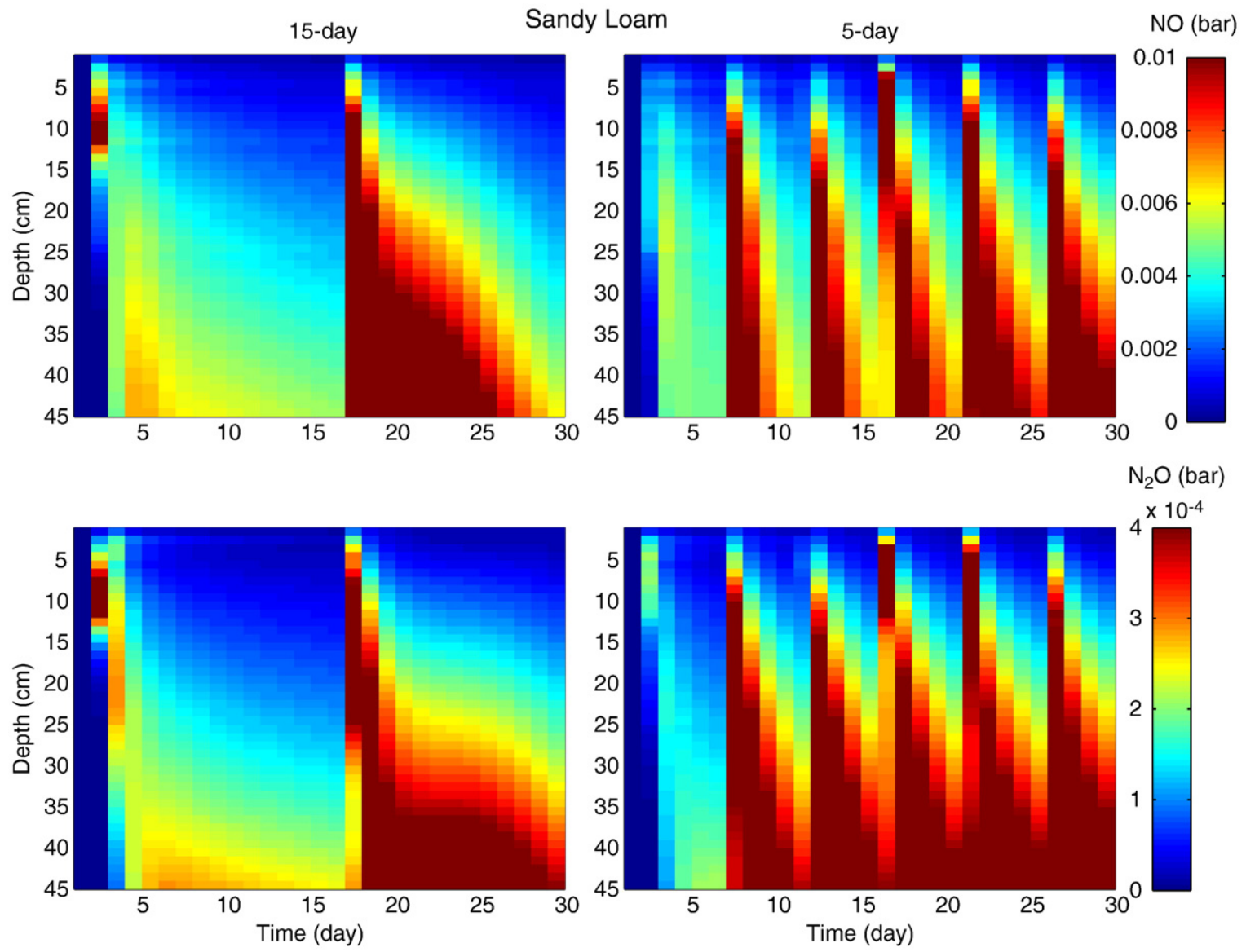

Fig. 8. Spatiotemporal dynamics of $\mathrm{NO}$ and $\mathrm{N}_{2} \mathrm{O}$ partial pressure in the sandy loam soil with 15 -day vs. 5-day at $15 \mathrm{~cm} \mathrm{month}^{-1}$ precipitation scenario. 

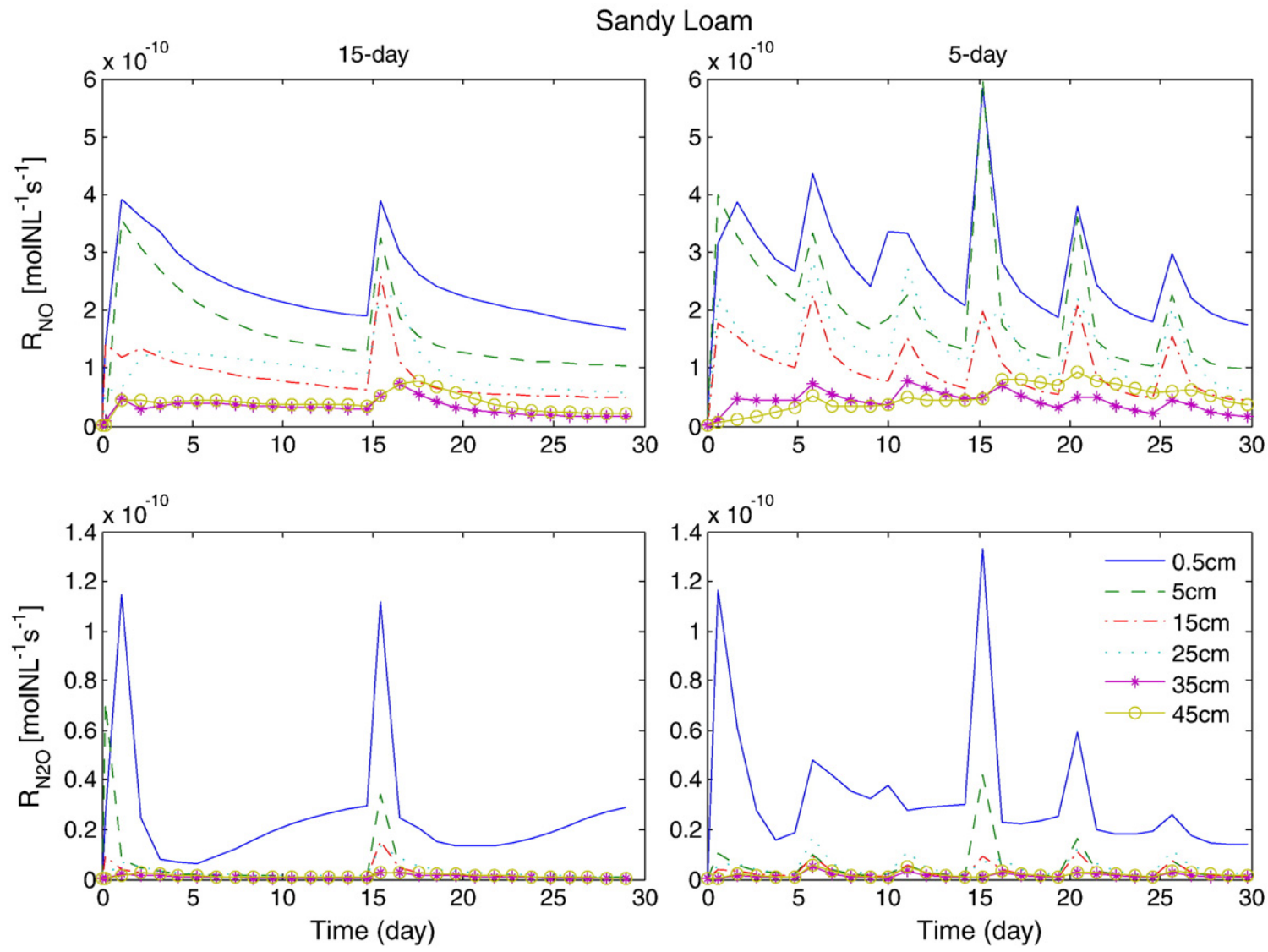

Fig. 9. Spatiotemporal dynamics of net production rates of $\mathrm{NO}$ and $\mathrm{N}_{2} \mathrm{O}$ in the sandy loam soil with 15 -day vs. 5-day at $15 \mathrm{~cm} \mathrm{month}^{-1}$ precipitation scenario. 